\title{
“Drakon”Algorithmic Language in Medical Care
} \author{
Kumpaitiene Birute ${ }^{2,3}$, Vaitkaitis Dinas ${ }^{2,3}$ and Krikscionaitiene Asta ${ }^{2,3}$ \\ ${ }^{1}$ Department of Obstetrics and gynaecology, Lithuanian University of Health Sciences, Lithuania \\ ${ }^{2}$ Crises research centre, Lithuania \\ ${ }^{3}$ Department of Disaster medicine, Lithuanian University of Health Sciences, Lithuania \\ ${ }^{4}$ Department of Infectious diseases, Lithuanian University of Health Sciences, Lithuania \\ ${ }^{5}$ Department of Emergency medicine, Lithuanian University of Health Sciences, Lithuania
}

Nadisauskiene Ruta ${ }^{*}$, Pukenyte Evelina ${ }^{2,4}$, Bardauskiene Lina ${ }^{5}$, Vileikyte Aiste², Dobozinskas Paulius ${ }^{2,3}$,

Submission: March 20, 2017; Published: April 27, 2017

*Corresponding author: Nadisauskiene Ruta, Department of Obstetrics and gynaecology, Lithuanian University of Health Sciences, Kaunas, Lithuania, Email: ruta.nadisauskiene@gmail.com

Abstract

The aims of algorithms in health care system are to indicate the right path of clinical decisions while standardizing and equalizing performance of practitioners. In addition, it improves the quality of health care and minimizes the risk of litigation. "DRAKON" algorithm is the ergonomic algorithm which helps to prevent mistakes and ambiguities. This article presents an algorithmic "DRAKON" language, which uniforms algorithms and allows complete clinical tasks successfully.

Keywords: Algorithm; DRAKON language; Medical care; Education

\section{Introduction}

Throughout 1980's and 1990's guidelines of all sorts were created. However, multiple studies demonstrated limited impact on physicians' decision making [1]. Diagnoses and treatment modalities differ all around the globe and some could lead to a variability of implementations and result in multiple outcomes. A well-designed algorithm could standardize and improve the path of diagnosis and treatment [2]. Studies suggest that algorithms improve the health care system and allow achieve a higher degree of standardization across patient management. Also, accurately applied algorithms based on the best available evidence lead to a more efficient treatment and better outcomes $[3,4]$. The vast volumes of literature on algorithms provide very little information on how to generate an ergonomic algorithm. Most of the resources simply include examples of algorithms without the unifying system.

The quality of algorithm is based not only on how concise and inclusive it is, but also weather the sequence of steps is logical and the terminology clear [5]. Obviously, one of the most important aspects of an algorithm is its efficiency [6]. In this article we introduce one of the most efficient ways of writing and reading algorithms called "DRAKON".

\section{Algorithmic “DRAKON” language}

"DRAKON" is a visual, graphic, and algorithmic programming language. This language was created following combined effort from Russian space agency and Russian Academy of Sciences in their collaborative work of building spaceship "Buran". Later this language was adapted to many other space industry projects [7]. Vladimir Parondzhanov is one of the creators of "DRAKON" language [8].

In aviation, oil industry, and the nuclear power plants ergonomic algorithms are widely used. The main advantage is interpretation of the action sequence in the same way by every user [9]. This resulted in exceptionally high safety records associated with previously mentioned industries. The WHO frequently indicates aviation industry as a gold safety standard. Any uncertainties make the algorithm difficult to read, interpret, understand, and follow. It increases the chance of mistake.

"DRAKON" helps to prevent mistakes and ambiguities. The motto of "DRAKON" language is: "the pathway of actions becomes clear at a glance" [10]. The ergonomic algorithms facilitate learning process, especially in emergency situations 
where coordinated approach from all team members is required [11].

\section{How to read "DRAKON" algorithms}

In order to read "DRAKON" charts, one needs to know 9 standardized icons and the sequence in which those icons are read. Each algorithm does not necesseraly contain all 9 icons. The number of icons depends on demand. There are two algorithmic drawings in DRAKON. Primitive is a simple chart without a tree. Silhouette contains several trees. The primitive algorithm is read vertically starting with the icon 'Start' and finishing at the 'End'.
If the algorithm includes several trees, three simple steps need to be followed: 1. read the names of trees horizontally from the left to right; 2. read each tree from the top to bottom in the vertical direction; 3. analyse each branch following questions, directions, or instructions.

Any type of "DRAKON" algorithm needs to be read strictly in the same order. There is no need to memorize each step because repeated use of algorithms eventually leads to automaticity. "DRAKON" charts allow performing different tasks at sequence. We are presented the "DRAKON" algorithm how to provide management in the third stage of delivery (Figure 1).

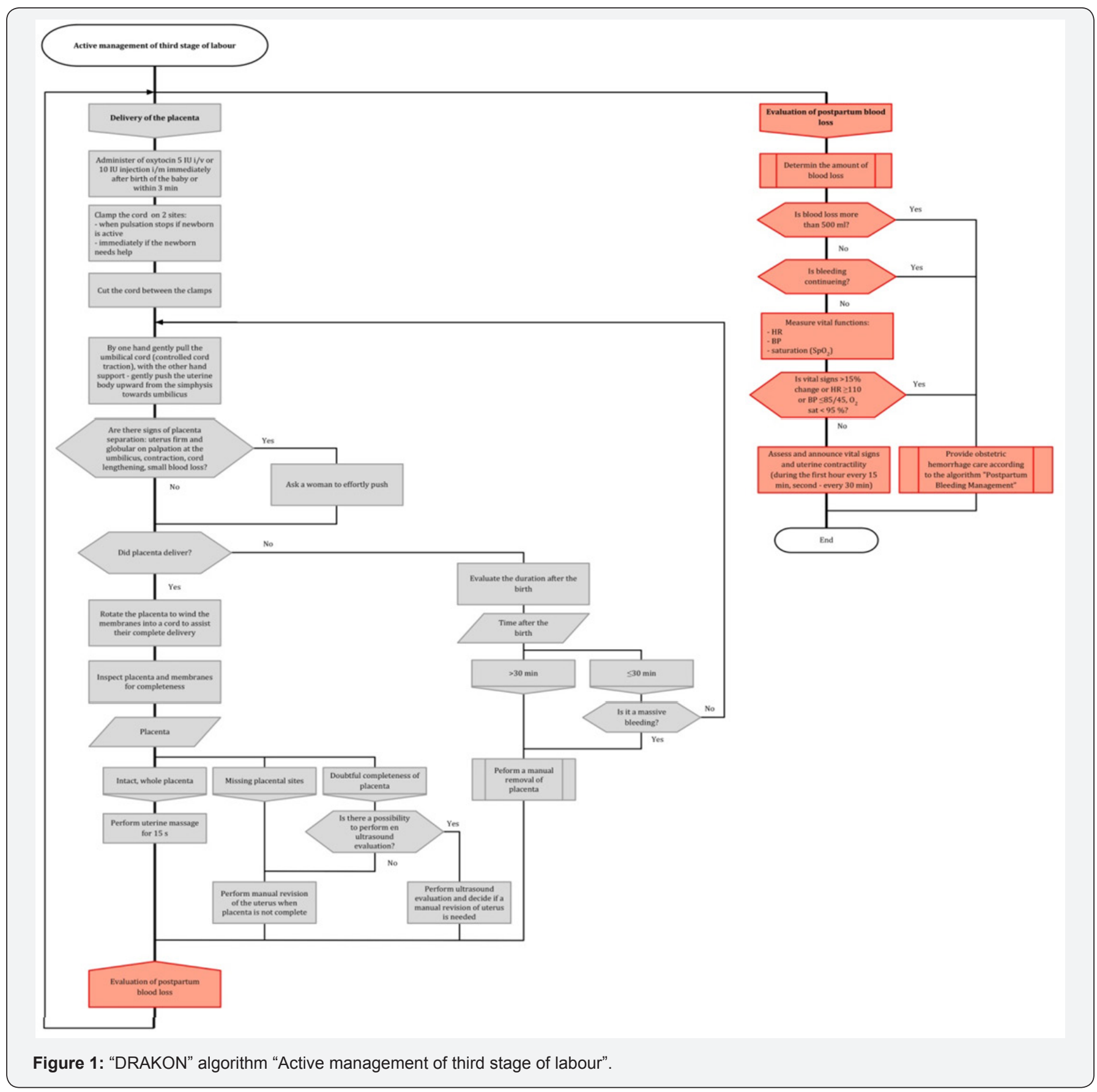




\section{Conclusion}

The importance of clinical algorithms in the patient diagnosis, treatment, and intervention is obvious. Similarly, algorithms are useful in education of medical practitioners, especially while working as a team. In order to maximize the utility of algorithms, they need to be simple, inclusive, and ergonomic, so that every user executes a specific algorithm in the identical manner. Medical care requires an instant implementation of latest scientific achievements. DRAKON algorithm can be used for practical "skills and drills" of undergraduate and postgraduate students. The "DRAKON" charts standardize, ensure quality of diagnostic and treatment procedures. It minimizes the possibility of error, thus, increases patient safety.

\section{References}

1. Keffer JH (2001) Guidelines and algorithms: Perceptions of why and when they are successfuland how to improve them. Clinical Chemistry 47(8): 1563-1572.

2. Hussey PS, Timbie JW, Burgette LF, Wenger NS, Nyweide DJ, et al (2015) Appropriateness of advanced diagnostic imaging ordering before and after implementation of clinical decision support systems. JAMA 313(21): 2181-2182.

3. Schoenbaum SC, Gottlieb LK (1990) Algorithm based improvement of clinical quality. Br Med J 301(6765): 1374-1376.
4. Trivedi MH, Claassen CA, Grannemann BD, Kashner TM, Carmody TJ, et al. (2007) Assessing physicians' use of treatment algorithms: Project IMPACTS study design and rationale. Contemp Clin Trials 28(2): 192212.

5. Cook R (2005) Clinical algorithms and flow charts as representations of guideline knowledge. Health care and informatics review online.

6. Mitkin S (2011) DRAKON The human revolution in understanding programs.

7. Паронджанов В (2012) Учись писать, читать и по-нимать алгоритмы. Алгоритмы для правиль-ного мышления. Основы алгоритмизации. ДМК Пресс, Russia.

8. Паронджанов В (2001)Как улучшить работу ума: Алгоритмы без программистов - это очень просто! Дело, р. 360.

9. WHO (2016) World Health Organization 10 facts on patient safety. World Health Organization, Geneva, Switzerland.

10. Паронджанов В (2010) Дружелюбные алгоритмы, понятные каждому. Как улучшить работу ума без лишних хлопот. ДМК Пресc, Russia.

11. Saeidiborojeni HR, Fakheri T, Jalalvand F, Soleimani P, Parse J, et al. (2012) Evaluation of algorithmic training efficacy in neurosurgical emergencies for medical students. Int J Collab Res Intern Med Public Health 4(6): 1231-1235.

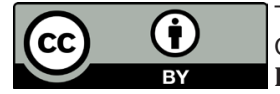

This work is licensed under Creative

Commons Attribution 4.0 Licens

DOI: $10.19080 / J G W H .2017 .04 .555636$

\section{Your next submission with Juniper Publishers will reach you the below assets}

- Quality Editorial service

- Swift Peer Review

- Reprints availability

- E-prints Service

- Manuscript Podcast for convenient understanding

- Global attainment for your research

- Manuscript accessibility in different formats

( Pdf, E-pub, Full Text, Audio)

- Unceasing customer service

Track the below URL for one-step submission https://juniperpublishers.com/online-submission.php 